\title{
UPAYA PERBAIKAN NUTRISI DAN PROFIL LIPIDATELUR PADA ITIK BALI YANG MENDAPATKAN SEKAM PADI MENGANDUNG DAUN NONI (Morinda citrifolia L) DISUPLEMENTASI MULTIENZIM
}

\author{
YADNYA, T. G. B., I W. WIRAWAN, A. A. P. P. WIBAWA, DAN N. M. S. SUKMAWATI \\ Fakultas Peternakan Universitas Udayana \\ e-mail: belawayadnya_fapet@yahoo.com
}

\begin{abstract}
ABSTRAK
Penelitian ini bertujuan untuk mengetahui upaya penurunan kadar kolesterol telur pada itik yang mendapatkan sekam padi yang mengandung daun noni (Morinda citrifolia L.) disuplementasi dengan multi enzim. Menggunakan rancangan acak lengkap dengan empat perlakuan yaitu ransum tanpa sekam padi, dan tanpa daun noni serta Starbio (A), ransum mengandung 10\% sekam padi (B), ransum mengandung 10\% sekam padi dan 5\% daun noni (C) dan ransum mengandung $10 \%$ sekam padi, $5 \%$ daun noni serta disuplementasi multi enzim (D). Setiap perlakuan terdiri dari tiga ulangan dan setiap ulangan berisi empat ekor itik. Variabel yang diamati adalah konsumsi ransum, konsumsi antioksidan ransum, dan profil lipida telur. Hasil penelitian menunjukkan bahwa pemberian $10 \%$ sekam padi dalam ransum (B) dapat meningkatkan konsumsi ransum secara nyata $(\mathrm{P}<0,05)$. Pemberian perlakuan $\mathrm{C}$ dan $\mathrm{D}$ dapat mengurangi konsumsi ransum serta meningkatkan kapasitas antioksidan ransum $(\mathrm{P}<0,05)$ dibandingkan perlakuan A. Pemberian perlakuan D juga dapat menekan total kolesterol, LDL, dan Trigliseriada sedangkan pada HDL meningkat secara nyata $(\mathrm{P}<0,05)$ dibandingkan dengan perlakuan A. Dari hasil penelitian dapat disimpulkan pemberian 10\% sekam padi yang mengandung daun noni (Morinda citrifolia L.) disuplementasi multi enzim dapat memperbaiki profil lipida telur itik bali pada fase peneluran pertama.
\end{abstract}

Kata kunci: profil lipida telur, sekam padi, multi enzim, daun noni, itik bali

\section{THE EFFORT TO IMPROVE NUTRITION AND EGG PROFILE LIPID ON BALI DUCK FED DIET WITH RICE HULL CONTAIN NONI (MORINDA CITRIFOLIA L) LEAF SUPPLEMENTED WITH MULTI ENZYME}

\begin{abstract}
The research was carried out to study the effect of egg cholesterol decrease of ducks fed with rice hull contain noni leaf (Morinda citrifolia L.) supplemented with multy enzyme. This study used a completely randomized design (CRD) consists of four treatments: diets without rice hull, noni leaf, and multi enzyme (A); diets with 10\% rice hull (B); diets with $10 \%$ rice hull and $5 \%$ noni leaves (C); and diets with $10 \%$ rice hull, $5 \%$ noni leaves and supplemented multi enzyme (D). There were three replicates and four ducks in each replication. The variables observed were diet consumption, antioxidant consumption and diet, and also egg lipid profile. The results showed that $10 \%$ rice hull in $\operatorname{diet}(\mathrm{B})$ can increase diet consumption significantly $(\mathrm{P}<0,05)$. Treatments $\mathrm{C}$ and $\mathrm{D}$ could decrease diet consumption and diet antioxidant capacity $(\mathrm{P}<0,05)$ compared to treatment $\mathrm{A}$. In addition, treatment $\mathrm{D}$ could also press the total of cholesterol, low density lipoprotein (LDL), and Triglyceride Acid (TGA). In contrast, high density lipoprotein (HDL) increased significantly compared to treatment A. The result showed that bali ducks fed with $10 \%$ rice hull contained noni leaf (Morinda citrifolia L.) and supplemented multi enzyme can increase lipid profile of bali duck eggs in the first phase.
\end{abstract}

Key world: egg lipid profile, rice hull, Morinda citrifolia L. leaf, multi enzym, bali duck eggs

\section{PENDAHULUAN}

Ternak itik sangat produktif untuk menghasilkan protein hewani yang dapat diperoleh dari daging dan telurnya (Murtidjo, 1988). Namun Setyawardani et al. (2001), daging itik atau telur kandungan kolesterolnya relatif tinggi, terutama telur mengandung kolesterol sebesar $340 \mathrm{mg} / 54 \mathrm{~g}$ telur (Anggorodi, 1984). 
Maka dari itu perlu dimanfaatkan bahan ransum yang mengandung senyawa yang bersifat antioksidan diantaranya adalah daun mengkudu (Morinda citrifolia L.) yang mengandung unsur selium (Se) dan magnesium (Mg) yang bersifat antioksidan yang dapat menetralkan radikal bebas, serta mengandung Xeronine yang mampu membantu dalam biosintesa protein (Bangu et al., 2002). Pemanfaatan bahan ransum yang mempunyai sifat antioksidan dapat dikombinasikan dengan bahan ransum yang berasal dari limbah pertanian atau agroindustri untuk mengurangi biaya pakan yang harus dikeluarkan dalam usaha peternakan berkisar 60\% (Nitis, 1980), diantaranya adalah sekam padi. Sekam padi mempunyai kandungan serat yang tinggi (35\%) dengan kandungan protein yang relatif rendah $(3,1 \%)$ (Lubis, 1992). Untuk itulah perlu dimanfaatkan zat probiotik diantarnya adalah Starbio (Lembah Hijau, 1993). Lebih lanjut dijelaskan bahwa Starbio mengandung enzim-enzim yang berguna dalam proses pencernaan, yaitu selulase untuk menghancurkan selulosa menjadi senyawa gula sederhana, misalnya glukosa (C6H12), lipase merombak lemak menjadi asam-asam lemak dan gliserol, dan protease merombak protein menjadi asam-asam amino. Yadnya et al. (2007) melaporkan fermentasi serbuk gergaji kayu dengan amoniasi urea dan larutan Effective Microorganism-4 (EM-4) dapat meningkatkan protein dari $0,91 \%$ menjadi $8,5 \%$ dan serat kasar dari $88 \%$ menjadi $48 \%$, dan dicoba pada ternak itik dengan pemberian $10 \%$ serbuk gergaji terfermentasi tidak berpengaruh terhadap penampilan, namun pada karkas dapat meningkat dan dapat menurunkan kolesterol darah itik. Roni dan Yadnya (2006) melaporkan pemberian ransum mengandung sekam padi diamoniasi urea dan starbio dapat memperbaiki bobot potong dan komposisi fisik karkas, lemak tubuh serta kualitas daging pada ayam broiler. Yadnya dan Sukmawati (2006) melaporkan penggantian dedak padi dengan 50\% serbuk gergaji kayu atau sekam padi yang suplememtasi Starbio tidak berpengaruh terhadap penampilan pada itik pada fase pertumbuhan. Yadnya (2010) melaporkan pemberian ransum sekam padi yang difermentasi dengan larutan EM-4 yang disuplementasi dengan Mono Sodium Glutamat (MSG) dapat meningkatkan penampilan pada itik bali. Susila et al. (2015) melaporkan pemberian ransum sekam padi yang difermentasi Arpergillus niger disuplementasi daun ubi jalar ungu dapat meningkatktkan penampilan serta memperbaiki kolesterol daging itik pada fase pertumbuhan.

Mengingat informasi yang terkait dengan pemanfaatan sekam padi yang disuplementasi Starbio sebagai sumber mikroorganisme yang dikombinasikan dengan daun noni masih kurang, maka perlu dicoba dalam suatu penelitian dengan judul upaya perbaikan nutrisi dan profil lipidatelur pada itik bali yang mendapatkan sekam padi mengandung daun noni (Morinda citrifolia L) disuplementasi multienzim.

\section{MATERI DAN METODE}

\section{Tempat dan Lama Penelitian}

Penelitian tentang kajian pemanfaatan sekam padi dalam ransum mengandung daun noni (Morinda citrifolia L.) dilakukan di dua tempat yaitu penelitian kandang dilaksanakan di Desa Guwang, Sukawati, Gianyar, Bali. Penelitian sifat kimia telur dilaksanakan di Lab. Nutrisi dan Makanan Ternak, Fakultas Peternakan, Universitas Udayana, terutama sifat kimia telur diantaranya kadar kolesterol termasuk HDL, LDL, dan Trigliserida, kadar air, protein, dan lemak, sifat fisik terdiri atas warna kuning telur, persentase putih, kuning dan kulit, indek dan berat jenis telur dilaksanakan di Lab. Kimia Biofisik, Fakultas Peternakan, Universitas Udayana, Kapasitas antioksidan dan antosianin ransum dilaksanakan di Lab. Kimia dan Mikroorganisme, Fakultas Teknologi Pertanian, Universitas Udayana.

\section{Itik}

Itik yang digunakan dalam penelitian adalah itik bali, umur 22 minggu sebanyak 100 ekor dengan umur dan berat yang homogen yang diperoleh dari seorang pengepul dari Kabupaten Gianyar.

\section{Kandang dan perlengkapannya}

Dalam penelitian ini menggunakan kandang sistem battery colony berlantai dua sebanyak 15 petak. setiap petak kandang mempunyai ukuran panjang $70 \mathrm{~cm}$, lebar $70 \mathrm{~cm}$, dan tinggi $70 \mathrm{~cm}$. Kandang dilengkapi dengan tempat makanan, dan tempat minum yang terbuat dari bilah-bilah bambu yang letaknya disebelah luar, dan juga dilengkapi dengan tempat penampung kotoran serta penampung sisa makanan, dan juga dilengkapi dengan lampu untuk penerangan di waktu malam.

\section{Komposisi Ransum}

Ransum terdiri dari jagung giling, kacang kedelai, bungkil kelapa, dedak padi, tepung ikan, mineral B12, garam dapur $(\mathrm{NaCl})$, dan sekam padi. Sekam padi ada yang tanpa diolah dan ada yang disuplementasi dengan multienzim yang berasal dari Starbio, dan daun noni (Morinda citrifolia L.).

\section{Rancangan Penelitian}

Rancangan penelitian yang dilaksanakan menggunakan rancangan acak lengkap (RAL) dengan empat perlakuan yaitu ransum tanpa sekam padi, daun noni dan Starbio (A), ransum mengandung 10\% sekam padi (B), ransum mengandung $10 \%$ sekam padi dan daun noni (C), dan ransum mengandung $10 \%$ sekam padi, 
Tabel 1. Komposisi bahan penyusunan ransum itik bali umur $22-34$ minggu

\begin{tabular}{lcccc}
\hline \multicolumn{1}{c}{ Komposisi bahan } & \multicolumn{4}{c}{ Perlakuan } \\
\cline { 2 - 5 } \multicolumn{1}{c}{ ransum (\%) } & $\mathrm{A}$ & $\mathrm{B}$ & $\mathrm{C}$ & $\mathrm{D}$ \\
\hline Jagung kuning & 55,36 & 49,98 & 49,98 & 47,32 \\
Kacang kedelai & 9,37 & 12,45 & 12,45 & 13,88 \\
Bungkil kelapa & 11,31 & 9,82 & 9,82 & 7,28 \\
Tepung ikan & 10,13 & 8,10 & 8,10 & 10,29 \\
Dedak padi & 13,26 & 9,00 & 9,00 & 5,55 \\
Sekampadi & - & 10,00 & 10,00 & 10,00 \\
Daun Noni & - & - & 5,00 & 5,00 \\
Mineral B12 & 0,50 & 0,50 & 0,50 & 0,50 \\
Multi-enzim (Starbio) & - & - & - & 0,01 \\
NaCl & 0,15 & 0,15 & 0,15 & 0,15 \\
Total & 100 & 100 & 100 & 100 \\
\hline
\end{tabular}

Keterangan

A: ransum tanpa mengandung sekam padi dan tanpa daun noni

B: ransum mengandung $10 \%$ sekam padi tanpa Starbio dan tanpa daun noni

C: ransum mengandung $10 \%$ sekam padi dan daun noni

D: ransum mengandung $10 \%$ sekam padi, daun noni dan Starbio

Tabel 2. Kandungan zat nutrisi dalam ransum penelitian itik bali umur 22-34 minggu

\begin{tabular}{lccccc}
\hline \multicolumn{1}{c}{$\begin{array}{c}\text { Kandungan zat } \\
\text { nutrisi }\end{array}$} & \multicolumn{4}{c}{ Perlakuan } & Standar \\
\cline { 2 - 6 } & $\mathrm{A}$ & $\mathrm{B}$ & $\mathrm{C}$ & $\mathrm{D}$ \\
\hline $\begin{array}{l}\text { Energi metabolisme } \\
\text { (Kkal/kg) }\end{array}$ & 28885,6 & 2860,8 & 2889,0 & 2895,2 & $2800-2900^{1)}$ \\
Protein kasar (\%) & 17,22 & 16,58 & 16,98 & 17,29 & $15-17^{2)}$ \\
Lemak kasar (\%) & 5,34 & 6,08 & 5,68 & 5,39 & $4-7^{3)}$ \\
Serat kasar (\%) & 6,90 & 7,76 & 6,80 & 6,11 & $3-8^{3)}$ \\
Kalsium (\%) & 0,94 & 0,78 & 0,85 & 0,95 & $0,80^{4)}$ \\
$\begin{array}{l}\text { Phosphor tersedia } \\
\text { (\%) }\end{array}$ & 0,51 & 0,52 & 0,55 & 0,58 & $0,60^{4)}$ \\
\hline
\end{tabular}

Keterangan :

1) NRC (1984). 2) Murtidjo (1988). 3) Morrison (1961) dan 4) Scott et al. (1982)

5\% daun noni dan Starbio (D). Setiap perlakuan dengan tiga ulangan, dan setiap ulangan berisi lima ekor itik betina umur 22 minggu dengan bobot badan yang homogen

\section{Variabel yang diamati meliputi:}

a. Konsumsi ransum: jumlah ransum yang diberikan selama penelitian dikurangi dengan sisa makanan

b. Kapasitas antioksidan ransum adalah kemampuan daripada antioksidan untuk mebetralkan radikal bebas

c. Profil lipida telur dengan metode Enzymatic Cholesterol High Performance (Broehriner, 1993).

\section{Analisis Statistika}

Data yang diperoleh dianalisis dengan sidik ragam dan apabila terdapat perbedaan yang nyata diantara perlakuan dilanjutkan dengan uji Duncan's (Steel dan Torrie, 1989).

\section{HASIL DAN PEMBAHASAN.}

\section{Konsumsi Ransum, Kapasitas Antioksidan Ransum, dan Nutrisi Telur}

Konsumsi ransum pada itik yang mendapatkan perlakuan A selama 12 minggu adalah 10,234 kg/ekor (Tabel 3). Pemberian ransum dengan 10\% sekam padi (perlakuan B) mengkonsumsi ransum 2,35\% lebih tinggi $(\mathrm{P}>0,05)$, sedangkan pemberian perlakuan $\mathrm{C}$ dan $\mathrm{D}$ dapat menekan konsumsi ransum secara nyata $(\mathrm{P}<0,05)$ daripada perlakuan $\mathrm{A}$. Adanya serat kasar yang tidak terfermentasi pada sekam padi yang menyebabkan kecernaan ransum lebih rendah, maka untuk memenuhi kebutuhan akan energi dan zat nutrisi lainnya maka itik harus mengkonsumsi lebih banyak agar kebutuhan energi dan zat gizi yang diperlukan bisa terpenuhi (Anggorodi, 1984). Kapasitas antioksidan ransum pada pemberian peralkuan A adalah $45,30 \%$ (Tabel 3). Pemberian ransum $\mathrm{B}$ dapat menurunkan kapasitas antioksidan secara tidak nyata $(\mathrm{P}>0,05)$, sedangkan dengan pemberian ransum $\mathrm{C}$ dan $\mathrm{D}$ dapat meningkatkan kapasitas antioksidan ransum sebesar 21,85\% dan 41,50\% $(\mathrm{P}<0,05)$ dibandingkan pemberian ransum A (kontrol). Peningkatan kapasitas antioksidan pada ransum $\mathrm{C}$ dan $\mathrm{D}$ disebabkan adanya daun noni yang bersifat antioksidan (Prangdimurti et al., 2012) yang menyebabkan kapasitas antioksidan ransum $\mathrm{C}$ dan D lebih besar dari pada ransum A atau B.

Tabel 3. Kajian pemanfaatan sekam padi dalam ransum yang mengadung daun noni (Morinda citrifolia L.) terhadap konsumsi ransum, kapasitas antioksidan ransum dan nutrisi telur itik

\begin{tabular}{crrrrr}
\hline & \multicolumn{5}{c}{ Variabel yang diamati } \\
\cline { 2 - 6 } $\begin{array}{c}\text { Per- } \\
\text { lakuan }\end{array}$ & $\begin{array}{c}\text { Konsumsi } \\
\text { ransum (kg/ } \\
\text { ekor) }\end{array}$ & $\begin{array}{c}\text { Kapasitas } \\
\text { antioksidan } \\
\text { ransum (\%) }\end{array}$ & $\begin{array}{c}\text { Kadar air } \\
\text { telur (\%) }\end{array}$ & $\begin{array}{c}\text { Kadar pro- } \\
\text { tein telur (\%) }\end{array}$ & $\begin{array}{c}\text { Kadar lemak } \\
\text { telur (\%) }\end{array}$ \\
\hline A & $\left.10,234 a^{2}\right)$ & 45,30c & $52,00 \mathrm{a}$ & $12,53 \mathrm{c}$ & $11,67 \mathrm{a}$ \\
B & $10,475 \mathrm{a}$ & 43,50c & $55,00 \mathrm{a}$ & $11,33 \mathrm{~d}$ & $12,30 \mathrm{a}$ \\
C & $9,684 \mathrm{~b}$ & $55,20 \mathrm{~b}$ & $47,50 \mathrm{~b}$ & $13,53 \mathrm{~b}$ & $10,40 \mathrm{~b}$ \\
D & $9,467 \mathrm{~b}$ & $64,10 \mathrm{a}$ & $38,50 \mathrm{~b}$ & $14,13 \mathrm{a}$ & $9,83 \mathrm{~b}$ \\
SEM & 0,036 & 0,917 & 1,7795 & 0,828 & 0,2089 \\
\hline
\end{tabular}

Keterangan:

1) A: ransum tanpa sekam padi (kontrol); B: ransum mengandung $10 \%$ sekam padi: $C$ : ransum mengandung $10 \%$ sekam padi dan daun noni; $D$ : ransum mengandung $10 \%$ sekam padi, daun noni dan Starbio

2) Nilai dengan huruf yang berbeda pada kolom yang sama berarti berbeda nyata $(P<0,05)$

3) SEM: Stardard Error of the Treatment Means

Kadar air, protein dan lemak telur pada itik yang mendapatkan ransum kontrol (A) adalah 52; 12,53 dan 11,67\% (Tabel 3). Pemberian ransum $B$ dapat meningkatkan kadar air berbeda tidak nyata $(\mathrm{P}>0,05)$, sedangkan dengan perlakuan $\mathrm{C}$ dan $\mathrm{D}$ dapat menurunkan kadar air secara nyata $(\mathrm{P}<0,05)$ daripada perlakuan A. Banyaknya kandungan air dalam telur sangat tergantung daripada besarnya berat kering dalam bahan. yang terkandung. Adanya daun noni mengandung xeronin 
(Bangun et al., 2002) yang dapat memacu biosintesa protein, kandungan protein meningkat yang menyebabkan berat kering telur meningkat, sedangkan kandungan lemak akan berkurang, dengan adanya lemak akan terhidrolisa menghasilkan air, sehingga pada perlakuan A dan B kadar airnya lebih tinggi daripada perlakuan C dan D.

Profil lipida terdiri atas total kolesterol (TK) high density lipoprotein (HDL), low density lipoprotein (LDL), dan Trigliserida (TGA) (Murray et al., 2009). Itik yang mendapatkan ransum tanpa sekam padi dan tanpa daun noni sebagai ransum kontrol (A) menghasilkan TK, HDL, LDL dan TGA adalah 246,35; 12,92; 134,48; dan 495,55 mg/100 g (Tabel 6.4). Pemberian perlakuan $\mathrm{B}$ dapat menurunkan total kolesterol telur secara tidak nyata $(\mathrm{P}>0,05)$, sedangkan pemberian perlakuan $\mathrm{C}$ dan $\mathrm{E}$ dapat menurunkan kadar kolesterol masing masing $13,67 \%$ dan $19,05 \%(\mathrm{P}<0,05)$ dibandingkan dengan pemberian perlakuan A. Penurunan kolesterol dalamdaging, karena adanya senyawa yang bersifat antioksidan,misalnya $\mathrm{Mg}$ dan Selium (Se) yang dapat mengaktikan aktivitas dari Superoksida dismutase (SOD) yang dapat menetralkan radikal bebas (Bangun et al., 2002). Adanya senyawa antioksidan dapat menghambat aktivitas kerja enzim 3 Hidroksi, Metyl-Gluteryl-Ko.A reduktase (Argawa dan Rao, 2002) sehingga berubahan dari Asam Mevalonat menjadi 3Hidroksi, 3 Metyl, Gluteryl-Ko.A berkurang produksinya, sehingga kolesterol yang terbentuk dalam jaringan atau hati berkurang sehingga kolesterol yang terakumulasi di dalam daging berkurang. Hasil penelitian ini sesuai yang diperoleh oleh Yadnya et al.,(2015), melaporkan pemberian kulit ubi jalar ungu terfermentasi dapat menurunkan kadar kolesterol pada darah dan pada daging itik bali fase pertumbuhan. Pemberian daun Noni dalam ransum juga dapat menurunkan kadar kolesterol pada darah itik bali.

Di dalam metabolisme lipoprotein ada dua sistem pengangkutan kolesterol dari hati ke jaringan perifer adalah Low Density Lipoprotein (LDL)dan yang mengangkut kolesterol dari bagian tepi ke hati adalah High Density Lipoprotein (HDL) (Wirahadikusumah, 1985). Pemberian perlakuan $B$ dapat meningkatkan HDL secara tidak nyata $(\mathrm{P}>0,05)$, sedangkan pemberian sekam padi tanpa fermentasi atau terfermentasi yang disuplementasi daun noni (perlakuan $\mathrm{C}$ dan $\mathrm{D}$ ) dapat meningkatkan kadar HDL berbeda nyata $(\mathrm{P}<0,05)$, dengan peningkatan kadar HDL untuk mencegah terjadinya penimbunan LDL pada dinding pembuluh darah. Pemberian perlakuan B, C dan D dapat menurunkan LDL telur, karena sebagian kolesterol telah dimanfaatkan oleh jaringan perifer, karena kapasitas antioksidan ransum meningkat yang dapat menagkal aktivitas radikal bebas (Kumalaningsih,
2008). Hasil penelitian sesuai dengan yang dicoba oleh Yadnya(2013). . Pemberian perlakuan B, C ternyata ada penurunan kadar TGA berbeda tidak nyata $(\mathrm{P}>0,05)$, sedangkan dengan pemberian perlakuan $\mathrm{D}$ dapat menurunkan kadar TGA sebesar 26,31\% $(\mathrm{P}<0,05)$ daripada perlakuan A.

Tabel 4. Profil lipida telur yang mendapatkan ransum asekam Padi terfermentasi disuplementasi daun ubi jalar ungu

\begin{tabular}{lccccc}
\hline \multirow{2}{*}{ Variabel } & \multicolumn{5}{c}{ Perlakuan } \\
\cline { 2 - 5 } & A & B & C & D & SEM ${ }^{2}$ ) \\
\hline $\begin{array}{l}\text { Total kolesterol } \\
\text { (mg/100 g) }\end{array}$ & $246,35 a^{1)}$ & $235,55 a$ & $212,65 b$ & $199,40 c$ & 3,960 \\
$\begin{array}{l}\text { High density lipoprotein } \\
\text { (g/100 g) }\end{array}$ & & & & \\
Low density lipoprotein & $134,48 \mathrm{~b}$ & $14,39 \mathrm{ab}$ & $15,70 \mathrm{a}$ & $15,67 \mathrm{a}$ & 0,58 \\
(mg/100 g) & & & & & \\
Trigliserida (mg/100 g) & $495,55 \mathrm{a}$ & $495,51 \mathrm{a}$ & $471,78 \mathrm{a}$ & $365,15 \mathrm{~b}$ & 13,52 \\
\hline
\end{tabular}

Keterangan;

1) Nilai dengan huruf yang berbeda pada kolom yang sama berarti berbeda nyata ( $P<$

2) SEM: Stardard Error of the Treatment Means

Besar kecilnya TGA sangat tergantung dari banyak sedikitnya gliserol dan asam lemak yang tersedia dalam makanan atau tergantung dari asupan ransum, Trigliserida akan terombak menjadi kolesterol dan asam lemak yang sangat bermanfaat dalam pembentukan VLDL (Very Low Density Lipoprotein) yang sangat berguna dalam metabolisme kolesterol (Wirahadikusumah, 1985). Hasil penelitian ini sesuai dengan yang diperoleh oleh Susila et al. (2016, unpublish), melaporkan pemberian sekam padi terfermentasi dapat menurunkan total kolesterol, menurunkan kadar LDL dan TGA serta dapat meningkatkan HDL daging itik bali fase pertumbuhan.

\section{SIMPULAN}

Berdasarkan hasil dan pembahasan hasil penelitian, maka dapat disimpulkan bahwa pemberian ransum sekam padi mengandung daun noni (Morinda citrifolia L.) disuplementasi multi enzim dapat meningkatkan kapasitas antioksidan ransum, dan memperbaiki profil lipida telur itik bali pada fase peneluran pertama.

\section{UCAPAN TERIMAKASIH}

Penulis mengucapkan ucapan terima kasih kepada Rektor Universitas Udayana/ Ketua Lembaga Penelitian dan Pengabdian kepada Masyarakat memberikan dana Hibah Unggulan Program Studi yang dibiayai oleh DIPA PNBP Universitas Udayana sesuai dengan Surat Perjanjian Penugasan Pelaksanaan Penelitian, Nomor :475A/UN14.1.25/PL/2016 tanggal 16 Maret 2016, melalui Dekan Fakultas Peternakan, Universitas 
Udayana sehingga penelitian dapat berjalan dengan semestinya.

\section{DAFTAR PUSTAKA}

Anggorodi, R. 1984. Ilmu Makanan ternak Umum. Penerbit PT Gramedia, Jakarta.

Apriyantono, A., D. Elias., J. J. Kelley, R. S. C. Lin, and I. R. K. Robson. 1989. Petunjuk Laboratorium Analisis Pangan. Departemen Pendidikan dan Kebudayaan, Direktorat Pendidikan Tinggi, Pusat Antar Universitas Pangan dan Gizi Institut Pertanian Bogor, Bogor.

Argawa, L. S, Rao, A.V. 200o. Role of Antioxidant Lycopene in Cancer and Heart Desease. J. Coll. Nutr. 19 (5): $563-9$

Bangun, A. P. Dan Sarwono, B. 2002. Sehat dengan Ramuan Tradisional Khasiat dan Manfaat Mengkudu. Agromedia Pustaka. Jakarta.

Bidura, I G. N. G. 2007. Aplikasi Produk Bioteknologi Pakan Ternak. Penerbit Universitas Udayana.

Hustiany, R. 2001. Identifikasi dan keragaman komponen off-odor pada daging itik. Skripsi, Fakultas Pascasarjana, Institut Pertanian Bogor, Bogor.

Jawi, I M., D. N. Suprapta, A. A. N. Subawa. 2008. Ubi Jalar Ungu Menurunkan Kadar MDA.dalam Darah dan Hati Mencit setelah Aktivitas Fisik Maksimal, Jurnal Veteriner, Juni 2008, ISSN:1411-8327.

Kumalaningsih, S. 2008. Antioksidan SOD (Superoksida dismutase) antioxidant. Centre.Com. Http ://antioxidant Centre, Com (Januari 2008).

Laconi, E. B. 1998. Peningkatan mutu cangkang kakao melalui amoniasi dengan urea dan biofermentasi dengan Pharenochaete chrysporium serta penjabarannya ke dalam formulasi ransum ruminansia. Desertasi, Program Pascasarjana, Institut Pertanian Bogor, Bogor.

Larmond.E. 1977. Laboratory Method for Sensory Evaluation of Food. Research Branch Canada. Department of Agriculture.

Lubis, D. A. 1992. Ilmu Makanan Ternak. PT. Pembanguan, Jakarta.

Murtidjo, B. A. 1988. Mengelola Itik. Kanisius, Yogyakarta.

Nitis, I M. 1980. Makanan ternak salah satu sarana untuk meningkatkan produksi ternak. Pidato Ilmiah Pengukuhan Guru Besar dalam Ilmu Makanan Ternak, FKHP, Universitas Udayana Denpasar.

Piliang, W.G. 1997. Straregi Penyediaan Pakan Berkelanjutan melalui Pemanfaatan Energi Alternatif, Orasi Ilmiah Guru Besar Tetap Ilmu Nutrisi Ternak.IPB, Bogor, 5 Juli 1997.

Prangdimurti, E., D. Mushtadi, D. M. Astawan, F. R. Zakaria. 2006. Kapasitas Antioksidan dan Hipokolesterolemik Ekstrak Daun Suji. http :// Respository.ipb. ac.id/123456789/42306.

Roni, N. G. K., N. M. S. Sukmawati, dan N. L. P. Sriyani.
2006. Pengaruh Pemberian Ransum Mengandung Sekam Padi Diamoniasi disuplementasi dengan Zat Probiotik terhadap Bobot Badan, Perlemakan Tubuh, dan Karkas Ayam Broiler. Laporan Penelitian, Fakultas Peternakan, Universitas Udayana.

Siregar, A. P., R. B. Cumming, and D. J. Farre. 1982. The Nutrition of Meat Type Ducks II. The Effect of Fibre on Biological Perfprmance and Carica Characteristic. Aust.J. Agric.R.

Soeparno. 2005. ilmu dan Teknologi Daging Gadjah Mada University, Press, Yogyakarta.

Setyawardani, T., D. Ningsih., D. Fernando, dan Arcawah. 2001. Pengaruh pemberian ekstrak buah nenas dan pepaya terhadap kualitas daging itik petelur afkir. Buletin Peternakan. Fakultas Peternakan, UGM, Yogyakarta, ISSN, 0126-4400, edisi Tambahan, Desember 2001.

Steel, R. G. D and J. M. Torrie. 1989. Priciples and Procedure of Statistic. Mc.Graw, Hill, Book Co Inc, New York, London.

Sumardika, I W. dan I M. Jawi. 2011.Pengaruh pemberian ekstrak daun ubi jalar ungu (Ipomoea batatas L) terhadap profil lipida dan superoksida dismutase (SOD) serum darah mencit. Prosiding International, $3^{\text {rd }}$ International Conference on Biociences and Biotechnology, Bali. September 21- 22.

Sukmawati, N. M., N. P. Sriyani, dan P. A. Astawa. 2008. Respon pemberian sagu cincang (Metroxylon sagu Rottb) dalam ransum disuplementasi Starnox terhadap peningkatan produksi dan perbaikan mutu fisik telur itik. Laporan Penelitian, Fakultas Peternakan, Universitas Udayana.

Susila, T. G. O., T. G. B. Yadnya, dan N. G. K. Roni. 2016. Kajian pemanfaatan sekam padi terfermentasi disuplementasi daun ubi jalar ungu terhadap kapasitas antioksidan ransum, karkas, dan kadar kolesterol daging pada itik bali. Laporan Penelitian Ungggulan DIKTI, Tahun Anggaran 2016, Fakultas Peternakan, Universitas Udayana, Denpasar.

Yadnya, T. G. B. dan N. M. S. Sukmawati. 2006. Pengaruh penggantian dedak padi dengan sekam padi dan Serbuk gergaji kayu tang disuplementasi dengan probiotik terhadap efisiensi penggunaan ransum dan kadar asam urat darah itik Bali. Majalah Ilmiah Peternakan. Fakultas Peternakan, Universitas Udayana, Terakreditasi No. 23a/DIKTI/Kep/2004, Volume 9, nomor 2, Tahun 2006, ISSN: $0853-8999$

Yadnya, T. G. B., N. M. S. Sukmawati, dan I K. M. Budiasa. 2007. Pengaruh pemberian serbuk gergaji kayu yang diamoniasi terfermentasi dan daun salam dalam ransum terhadap penampilan, karkas dan kadar kolesterol darah itik bali. Prosiding Seminar Nasional, Fakultas Peternakan, UGM, Yogyakarta, 24 - 27 Juli 2007.

Yadnya, T. G. B. dan I M. Mudita. 2010. Pengaruh Pembem- 
berian Monosodium Glutamat (MSG) dalam Ransum yang Disuplementasi dengan Larutan Effective Microorganism-4 (EM-4) terhadap karkas, Asam Urat dan Kadar Protein Darah Itik Campbell. Seminar Nasional, BPTP. Denpasar Bali.

Yadnya, T. G. B. and A. A. A. S. Trisnadewi. 2011. Inproving the Nutritive of Purple Sweet Potato (Ipomoea batatas L) through Biofermentasi of Aspergillus niger as Feed Substance Containing Antioxidant. International. $3^{\text {rd }}$ International Conference on Biosciences and Biotechnology, Bali, September 21 - 22, 2011.

Yadnya, T. G. B., I. B. G. Partama, dan A. A. A. S. Trisnadewi 2012. Pengaruh pemberian ransum yang mengandung ubi jalar ungu (Ipomoea batatas L) terfermentasi Aspergillus niger terhadap kecernaan ransum, retensi protein, dan pertambahan bobot badan itik bali. Pro- siding Semnas FAI 2012 ISBN: 978 - $602-18810-0$ - 2. Universitas Mercu Buana, Yogyakarta.

Yadnya, T. G. B., N. M. S. Sukmawati, dan I W. Wirawan. 2013. Pemanfaatan daun ubi jalar ungu dalam ransum disuplementasi Starpig terhadap kadar kolesterol serum darah dan karkas itik bali. Makalah Seminar Nasional. Fakultas Agroindustri, Universitas Mercu Buana, Yogyakarta, 9 Oktober 2013.

Yadnya, T. G. B., I G. L. Oka, I G. A. I. Aryani, dan A. A. A. S. Trisnadewi. 2013. Kajian Pengaruh Pemanfaatan Daun Ubi Jalar Ungu (Ipomoea batatas L), Daun Mengkudu (Morinda citrifolia L), dan Daun Sirih) (Piper betle L) dalam Ransum terhadap Profil Kimia Darah Itik Bali. Laporan Penelitian, Fakultas Peternakan, Universitas Udayana. 